\title{
Konsepsi Hak Asasi Manusia dan Implementasinya di Indonesia
}

\author{
Bambang Sutiyoso
}

The issues of human rights constitute the global issues recently that will not ignore with some reasons including in Indonesia. The concept of human rights and its realization in each state may not similar although actually the substance of human rights is equal. In this respect there are three concepts and implementations of human right in the world that be regarded as the representatives of western states, Socialism -communism and Islamic doctrine. The consequence of human rights emerges human obligations, that both human rights and human obligations are parallel and a system. The ignoring one of them will raise heavy infraction of human rights itself. The Implementation of human rights in Indonesia particularly even though many cases emerge generally either development or the maintenance of human rights seems the progress. In this sense, the regulating law of human rights by legislating the rules and by establishing the Human Rights Court in overcoming many cases of heavy evading of raised human rights.

Istilah hak-hak asasi manusia dalam beberapa bahasa asing dikenal dengan sebutan sebagai berikut: droit de l'home (Perancis) yang berarti hak manusia, $h u-$ man right (Inggris) atau mensen rechten (Belanda), yang dalam bahasa Indonesia disalin menjadi hak-hak kemanusiaan atau hak-hak asasi manusia. ${ }^{2}$

Hak asasi manusia (HAM) pada hakekatnya merupakan hak kodrati yang secara inheren melekat dalam setiap diri manusia sejak lahir. Pengertian ini mengandung arti bahwa HAM merupakan karunia Allah Yang Maha Pencipta kepada hamba-Nya. Mengingat HAM itu adalah karunia Allah, maka tidak ada badan apapun yang dapat mencabut hak itu dari tangan pemiliknya. Demikian pula tidak ada seorangpun diperkenankan untuk merampasnya, serta tidak ada kekuasaan apapun yang boleh membelenggunya. ${ }^{2}$

Karena HAM itu bersifat kodrati, sebenarnya ia tidak memerlukan legitimasi yuridis untuk pemberlakuannya dalam suatu sistem hukum nasional maupun internasional. Sekalipun tidak ada perlindungan dan jaminan konstitusional terhadap HAM, hak itu tetap eksis dalam setiap diri manusia. Gagasan HAM yang bersifat teistik ini diakui kebenarannya sebagai nilai yang paling hakiki dalam kehidupan manusia. Namun karena

'Marsudi, Subandi Al., 2001, Pancasila dan UUD 45 dalam Paradigma Reformasi, Jakarta: PT RajaGrafindo Persada, hlm. 83.

${ }^{2}$ Pengertian yang hampir sama juga dinyatakan dalam Ketetapan MPR RI No. XVII/MPR/ 1998 tentang Hak Asasi Manusia yang diuraikan dalam lampiran ketetapan ini berupa naskah Hak Asasi Manusia pada angka I huruf D butir 1 menyebutkan : "Hak asasi manusia adalah hak sebagai anugerah Tuhan Yang Maha Esa, yang melekat pada diri manusia, bersifat kodrati, universal dan abadi, berkaitan dengan harkat dan martabat manusia". Selanjut 
sebagian besar tata kehidupan manusia bersifat sekuler dan positivistik, maka eksistensi HAM memerlukan landasan yuridis untuk diberlakukan dalam mengatur kehidupan manusia. ${ }^{3}$

Dalam perspektif sejarah hukum, setiap ada penyalahgunaan kekuasaan yang berimplikasi terhadap perampasan, perkosaan dan pemanipulasian HAM oleh manusia satu kepada manusia yang lain atau oleh penguasa kepada rakyatnya akan selalu muncul krisis kemanusiaan. Bahkan kemudian memunculkan formula-formula atau dokumen-dokumen resmi hak-hak asasi manusia atau sumber hukum yang memberi hak bagi rakyat. Misalnya dokumen Magna Charta di Inggris tahun 1215 yang memberikan hak-hak bagi rakyat dan sekaligus membatasi kekuasaan raja. Kemudian dokumen The Virginia Bill of Rights dan declarations of Independence yang melahirkan kemerdekaan Amerika Serikat tahun 1776, yang berisi jaminan kebebasan individu terhadap kekuasaan negara. Begitu pula dokumen Declarations des Droites L'Home et Du Cituyen di Prancis tahun 1789 yang berprinsip bahwa manusia pada hakekatnya adalah baik dan karenanya harus hidup bebas dan sama kedudukannya dalam hukum. Di Rusia tahun 1918, juga muncul suatu dokumen yang menyebut hak-hak dasar sosial, tetapi hak-hak dasar individu tidak disebut sama sekali. Selanjutnya dokumen Declarations of Human Rights tahun 1948 yang dikeluarkan oleh Perserikatan BangsaBangsa (PBB) yang menjamin hak-hak sipil, hak-hak sosial dan hak-hak kebebasan politik.

Secara filosofis berbagai dokumen hakhak asasi manusia tersebut terdapat adanya perbedaan muatan nilai dan orientasi. Di Inggris menekankan pada pembatasan kekuasaan raja, di Amerika Serikat mengutamakan kebebasan individu, di Perancis memprioritaskan egalitarianisme persamaan kedudukan di hadapan hukum, di Rusia tidak diperkenalkan hak individu tetapi hanya mengakui hak sosial. Sementara itu Perserikatan Bangsa-Bangsa merangkum berbagai nilai dan orientasi karena Deklarasi Umum Hak Asasi Manusia di badan dunia ini sebagai kesepakatan berbagai negara setelah mengalami revolusi Perang Dunia II, yang menelorkan pengakuan prinsip kebebasan perseorangan, kekuasaan hukum dan demokrasi sebagaimana diformulasikan dalam preambule Atlantik Charter $1945 .{ }^{4}$

Dokumen dan kesaksian sejarah tersebut menunjukkan bahwa setiap terjadi krisis hak asasi manusia selalu muncul revolusi atau gejolak sosial. Seperti halnya krisis hak asasi manusia di negara-negara komunis tahun 1990 yang menghancurkan tembok Berlin dan penghancuran patung patung tokoh mereka yang sebelumnya dipuja-puja. Rangkaian kesaksian sejarah tersebut menunjukkan bahwa hak asas manusia merupakan konstitusi kehidupan, karena hak asasi manusia merupakan prasyarat yang harus ada dalam setiap kehidupan manusia dan merupakan bekal bagi setiap insan untuk dapat hidup sesuai fitrah kemanusiaannya.

nya dalam Pasal 1 angka 1 UU No. 39 Tahun 1999 tentang Hak Asasi Manusia, menyatakan: "Hak asasi manusia adalah seperangkat hak yang melekat pada hakikat dan keberadaan manusia sebagai mahluk Tuhan Yang Maha Esa dan merupakan anugerah-Nya yang wajib dihormati, dijunjung tinggi dan dilindungi oleh negara, hukum dan pemerintah, dan setiap orang demi kehormatan serta perlindungan harkat dan martabat manusian.

${ }^{3}$ Luthan, Salman., "Proyeksi Harmonisasi Konvensi Menentang Penyiksaan Dengan Hukum Pidana Nasional", makalah seminar nasional kerjasama Departemen Hukum Internasional FH UII dengan ELSAM, Yogyakarta, 1995.

4Alkostar, Artidjo., 1994, "Hak Asasi Manusia dalam Perspektif Penegakkan Hukum Dewasa Ini", Makalah dalam rangka Dies Natalis UII ke 51, Yogyakarta, hlm. 3 . 
Perjuangan dan perkembangan hak-hak asasi manusia di setiap negara mempunyai latar belakang sejarah sendiri-sendiri sesuai dengan perjalanan hidup bangsanya, meskipun demikian sifat dan hakikat HAM di mana-mana pada dasarnya adalah sama. Dalam konteks itulah, tulisan berikut ini akan mengungkapkan beberapa konsepsi dan model pelaksanaan HAM, yaitu di negara-negara Barat yang sebagian besar menganut paham liberal kapitalis dan negara-negara pengikut aliran komunissosialis serta konsepsi dan model HAM menurut ajaran Islam. Ketiga sistem ini dapat dianggap mewakili berbagai konsepsi HAM yang ada, mengingat sebagian besar dari mereka berkiblat dan mengacu salah satu dari ketiga sistem tersebut. Selain itu dikemukakan pula tentang HAM dan implementasinya di Indonesia, dengan mengupas seputar perkembangan dan penegakkan HAM di Indonesia.

\section{Konsepsi dan Model Pelaksanaan HAM}

Seperti diketahui, bahwa HAM itu adalah bersifat universal. Namun demikian pelaksanaan HAM tidak mungkin disamaratakan antara satu negara dengan negara yang lain. Masing-masing negara tentu mempunyai perbedaan konteks sosial, kultural maupun hukumnya. Di samping itu pengalaman sejarah dan perkembangan masyarakat sangat mempengaruhi implementasi HAM tersebut. Keuniversalan HAM dewasa ini masih mengundang perdebatan dan perbedaan dalam praktek penerapannya di antara masing-masing anggota Perserikatan Bangsa-Bangsa. Hal ini dapat dilihat dalam perspektif filsafat hukum atau ideologi yang melatarbelakangi norma hukum atau negara yang bersangkutan.
Pengakuan dan potret pelaksanaan HAM di negara komunis dapat dilihat dari watak aturan hukumnya yang tidak memberi tempat adanya hubungan hukum privat, karena segala sesuatu dianggap dari masyarakat dan untuk kepentingan masyarakat. Semua hukum menjadi administrasi kebijakan penguasa, karena itu hukum harus mengabdi pada politik partai. Demikian pula pengadilan harus tunduk pada pengawasan kekuasaan poliitik partai. Kondisi demikian antara lain tergambar dalam buku The Gulag Archipelago, karangan Alexander Solshenitsyn yang melukiskan tentang pelecehan HAM di Rusia, hukum sebagai alat kekuasaan dan pengadilan dilakukan dibelakang pintu tertutup. Hal serupa juga terjadi pada Fascis dan Nazi yang menonjolkan despotisme, dalam diri negara merupakan hukum, yaitu legitimasi nafsu penguasa untuk menguasai dan mendominasi hak asasi rakyat. Sedangkan konsepsi dan pemberlakuan HAM di negara liberal kapitalis dapat dilihat dari karakter aturan hukumnya yang berakar pada filsafat individualisme-utilitarian. Tujuan filsafat ini adalah emansipasi individu dan orientasinya adalah menambah kesenangan individu. Hukum yang dianggap baik adalah hukum yang memanjakan kebebasan bagi setiap individu dan memacu agar setiap individu mengejar apa yang dianggap baik bagi dirinya. Falsafah ini pula yang menjadi akar dari prinsip "Laissez Faire" dalam dunia perekonomian dewasa ini. Perekonomian dunia didorong mengarah pada mekanisme persaingan bebas yang diyakini akan menghasilkan kebahagiaan yang maksimal bagi setiap individu. ${ }^{5}$

Terhadap konsepsi dan praktek-praktek di atas, seorang filosof muslim, Dr. Mohammad Iqbal (1873-1938) sebagaimana dikutip Moh. Natsir pernah

${ }^{5}$ Alkostar, Artidjo., Ibid, hIm. 4 . 
mengemukakan bahwa baik kapitalisme Barat dan sosialisme Marxis, pada asasnya berdasarklan nilai-nilai kebendaan dari kehidupan serta kosong dari warisan ruhaniyah.-Sosialisme Karl Marx sebagai suatu rencana yang berdasarkan kesamaan perut (equality of stomach) dan bukan kesamaan ruh. Demikian jugá kapitalisme; imperialisme, - kolonialisme dan rasionalisme 'dilukiskan' sebagai kegemukan jasad. ${ }^{6}$

Pada šaat yang sama, sudah masanya PBB sebagai badan dunia mengevaluasi konsep dasar HAM yang dipakainya serta praktek pelaksanaannya agar eksistensi keberadaannya tidak kehilangan relevansi sosio humanisnya. Konsep HAM. PBB yang hanya menonjolkan hak dan tanpa kewajiban asasi, perlu dipertanyakan secara kritis dalam hubungannya déngan banyaknya benturan dan konflik HAM yang banyak memakan korban jiwa dan martabat manusia, baik secara sistemik misalnya agresi suatu negara terhadap negara lain, maupun secara evolutif misalnya munculnya euthanasia, aborsi dan lain sejenisnya.

Konsep - dan prototipe realisasi kewajiban asasi dan HAM yang dilandasi nilai-nilai yang sempurna telah dicontohkan secara faktual oleh segala bangsa di dunia, yaitu setiap tanggal 10 Dzulhijjah di kota Makkah atau saat pelaksanaan ibadah haji. Di mana segala bangsa di dunia berkumpul dengan tujuan yang sama, pakaian yang sama, merasa berkedudukan yang sama dan hanya tunduk kepada kekuasaan Allah Yang Maha Esa. Namun tampaknya PBB belum rela secara resmi untuk menarik kesimpulan dan mengambil esensi konsep yang mendasari konstruksi hubungan kemanúsiaan dan sosial yang harmonis di kota Makkah itu.
Sebenarnya yang perlu ditelaah sekarang oleh masyarakat dan bangsabangsa di dunia karena konsepsi dan faktafakta pelaksanaannya terbukti merupakan: perwujudan dari 'suatu konstitusi. kehidupan manusia yang diajarkan dan dicontohkan oleh seorang pemimpin masyarakat bangsa, pembela dan pengangkat martabat manusia, yaitu Nabi Muhammad SAW (571-633). Arah dan dán landasan pembinaan martabat dan hak-hak. kemanusiaannya mempunyai kejelasan serta keharmonisan antara kewajiban asasi dan hak asasi, antara hak individu dan hak masyarakat. Lebih dari itu, karena berdasarkan kepastian rohani yang mampu memahami tujuan hidup manusia, yaitu pengabdiän kepada Allah SWT.

Bertitik tolak dari konsepsi Islam tersebut pulalah lebih jauh Dr. Mohammiad Iqbal mengemukakan bahwa Islam pada hakekatnya adalah tauhid. Inti dari tauhid adalah working idea dan cita yang fa'al inilah membuahkan Keesaan dan kemerdekaan. Islam memberikan beberapa asas nyata seperti demokrasi dan kemerdekaan. Kemerdekaan pikiran dan menyatakan pendapat, kemerdekaan beragama, keesaan, 'toleransi, keadilan sosial dan lain sebagainya. Bersamaan dengan hak-hak manusia yang asasi ini, Islam juga menetapkan beberapa kewajiban manusia yang asasi untuk-mencapai kesejahteraan hidup berjamaah bagi selurüh umat manusia: ${ }^{7}$

Seorang guru besar hukum dari Monash University, bernama Christopher G. Weermantry, dalam seminar internasional tentang HAM di Jenewa bulan Desember 1988, seperti dikutip 'Marjonó Reksodiputro, ${ }^{8}$ secara jujur mengatakan: "Ajaran Islam datang jauh lebih dahulu daripada negara Barat, yang inti ajarannya tentang HAM menyatakan bahwa bahwa!

${ }^{6}$ Natsir, Moh., 1953, Dapatkah Dipisahkan Politik dan Agama?, Jakarta: Mutiara, hlm. 19. IIbid., hlm. 22.

${ }^{8}$ Lihat Alkostar, Artidjo., Op.Cit., hlm. 11. 
hak-hak dasar tidak dapat dicabut dan para penguasa melaksanakan kekuasaanya atas dasar kepercayaan dan hanya sepanjang kehormatan penguasa itu benar. Prinsipprinsip ini merupakan inti dari teori politik Islam, di mana enam ratus tahun sebelum John Locke mengemukakan teorinya di Barat".

Kesadaran untuk menegakkan HAM, sebagaimana diisyaratkan dalam Islam bahwa memperjuangkan dan menikmati hak asasi adalah merupakan kewajiban yang suci, seperti ditegaskan dalam AIQur'an Surat Al-Qashash: 77 yang artinya: "Dan carilah pada apa yang telah dianugerahkan Allah kepadamu (kebahagiaan) negeri Akherat, dan janganlah kamu melupakan kebahagiaan (kenikmatan, hak-hak) duniawi dan berbuat baiklah (kepada orang lain), sebagaimana Allah telah berbuat baik kepadamu, dan janganlah kamu berbuat kerusakan di muka bumi. Sesungguhnya Allah tidak menyukai orang-orang yang berbuat kerusakan". Di samping itu masih banyak ayat-ayat lain yang mengungkapkan perlunya menegakkan HAM dan martabatnya, seperti yang tertcantum dalam Q.S. Asy-Syura: 39, QS. Ali Imran : 171, QS. An-Nahl: 110, QS. AnNisa : 97 , QS. Ali Imran: $135,{ }^{\circ}$ S. An-Nisa : 107 dan sebagainya.

Hak asasi dalam perspektif Islam, terdapat dalam setiap sektor kehidupan, serta memiliki posisi strategis dalam menegakkan dan meningkatkan kualitas kemanusiaan. Bahkan interrelasi antara hak asasi dan kewajiban asasi antara lain dapat ditunjukkan mempunyai nilai keutamaan akhlak, apabila dilakukan dengan cara menegakkan keadilan atau menyampaikan perkataan yang benar di hadapan penguasa yang menyeleweng. Dalam hubungan ini terlihat bahwa proses penegakkan hukum dan keadilan menuntut adanya spirit amar ma'ruf nahi munkar.
Nilai kejuangan dalam penegakkan hukum dan keadilan, antara lain karena di dalamnya banyak godaan dan tantangan serta menuntut pengorbanan serta keikhlasan sikap dalam rangka melindungi hak asasi manusia.9

Kewajiban asasi manusia menjadi prasyarat utama agar dalam menjalankan hidup dan kehidupannya memiliki keseimbangan dan ketenangan jiwa serta menjadikan hidupnya bermakna bagi dirinya sendiri, keluarganya, lingkungannya serta masa depannya. Hubungan erat antara kewajiban asasi dan hak asasi, menunjukkan adanya kesempatan pemberian bagi individu dalam sikapnya, masyarakat dalam tradisinya, negara atau kelompok negara dalam budaya hukumnya.

Hubungan etis antara kewajiban asasi dengan hak asasi, menuntut konsistensi sikap agar seseorang, masyarakat atau bangsa tidak berat sebelah dalam melakukan peran diri dan hubungan sosialnya, karena pada dasarnya seseorang, masyarakat atau bangsa tidak dapat hidup dengan baik dan benar, kalau hanya melakukan atau menuntut hak asasinya saja tanpa melakukan kewajiban asasi secara seimbang. Bahkan dalam konsepsi Islam, kewajiban asasi menjadi keutamaan moral untuk didahulukan dibandingkan dengan hak asasi itu sendiri.

\section{Perkembangan HAM di Indonesia}

Berbeda dengan Inggris dan Perancis yang mengawali sejarah perkembangan dan perjuangan hak asasi manusianya dengan menampilkan sosok pertentangan kepentingan antara kaum bangsawan dan rajanya yang lebih banyak mewakili kepentingan lapisan atas atau golongan tertentu saja. Perjuangan hak-hak asasi

9lbid., hlm. 16-17. 
manusia Indonesia mencerminkan bentuk pertentangan kepentingan yang lebih besar, dapat dikatakan terjadi sejak masuk dan bercokolnya bangsa asing di Indonesia dalam jangka waktu yang lama. Sehingga timbul berbagai perlawanan dari rakyat untuk mengusir penjajah.

Dengan demikian sifat perjuangan dalam mewujudkan tegaknya HAM di Indonesia itu tidak bisa dilihat sebagai pertentangan yang hanya mewakili kepentingan suatu golongan tertentu saja, melainkan menyangkut kepentingan bangsa Indonesia secara utuh. Hal ini tidak berarti bahwa sebelum bangsa Indonesia mengalami masa penjajahan bangsa asing, tidak pernah mengalami gejolak berupa timbulnya penindasan manusia atas manusia. Pertentangan kepentingan manusia dengan segala atributnya (sebagai raja, penguasa, bangsawan, pembesar dan seterusnya) akan selalu ada dan timbul tenggelam sejalan dengan perkembangan peradaban manusia. Hanya saja di bumi Nusantara warna pertentanganpertentangan yang ada tidak begitu menonjol dalam panggung sejarah, bahkan sebaliknya dalam catatan sejarah yang ada berupa kejayaan bangsa Indonesia ketika berhasil dipersatukan di bawah panji-panji kebesaran Sriwijaya pada abad VII hingga pertengahan abad IX, dan kerajaan Majapahit sekitar abad XII hingga permulaan abad XVI. ${ }^{10}$

Diskursus tentang HAM memasuki babakan baru, pada saat Badan Penyelidik Usaha Persiapan Kemerdekaan Indonesia (BPUPKI) yang bertugas menyiapkan rancangan UUD pada tahun 1945, dalam pembahasan-pembahasan tentang sebuah konstitusi bagi negara yang akan segera merdeka, silang selisih tentang perumusan HAM sesungguhnya telah muncul. Di sana terjadi perbedaan antara Soekarno dan Soepomo di satu pihak dan Mohammad Hatta dan Mohammad Yamin di pihak lain. Pihak yang pertama menolak dimasukkannya HAM terutama yang bersifat individual ke dalam UUD karena menurut mereka Indonesia harus dibangun sebagai negara kekeluargaan. Sedangkan pihak kedua menghendaki agar UUD itu memuat masalah-masalah HAM secara eksplisit."

Sehari kemerdekaan, tanggal 18 Agustus 1945, Panitia Persiapan Kemerdekaan Indonesia (PPKI) mengadakan sidang untuk mengesahkan UUD 1945 sebagai UUD negara Republik Indonesia. Dengan demikian terwujudlah perangkat hukum yang di dalamnya memuat hak-hak dasar manusia Indonesia serta kewajibankewajiban yang bersifat dasar pula. Seperti yang tertuang dalam Pembukaan, pernyataan mengenai hak-hak asasi manusia tidak mendahulukan hak-hak asasi individu, melainkan pengakuan atas hak yang bersifat umum, yaitu hak bangsa. $\mathrm{Hal}$ ini seirama dengan latar belakang perjuangan hak-hak asasi manusia Indonesia, yang bersifat kebangsaan dan bukan bersifat individu. ${ }^{12}$ Sedangkan istilah atau perkataan hak asasi manusia itu sendiri sebenarnya tidak dijumpai dalam UUD 1945 baik dalam pembukaan, batang tubuh, maupun penjelasannya. Istilah yang dapat ditemukan adalah pencantuman dengan tegas perkataan hak dan kewajiban warga negara, dan hak-hak Dewan Perwakilan Rakyat. Baru setelah UUD 10八. mengalami perubahan atau amandemen

${ }^{10}$ Marsudi, Subandi Al., Op. Cit., hlm. 90.

"Mahfud, Moh., 1999, Hukum dan Pilar-pilar Demokrasi, Yogyakarta: Gama Media, hlm. 110.

${ }^{12}$ Marsudi, Subandi Al., Op. Cit., hlm. 95.

${ }^{13}$ Ahadian, Ridwan Indra., 1991, Hak Asasi Manusia dalam UUD 1945, Jakarta: CV. Haji Masagung, Jakarta, hlm. 15. 
kedua, istilah hak asasi manusia dicantumkan secara tegas. ${ }^{33}$

Dalam sejarah ketatanegaraan Indonesia pernah mengalami perubahan konstitusi dari UUD 1945 menjadi konśtitusi RIS (1949), yang di dalamnya memuat ketentuan hak-hak asasi manusia yang tercantum dalam Pasal 7 sampai dengan 33. Sedangkan setelah konstitusi RIS berubah menjadi UUDS (1950), ketentuan mengenai hak-hak asasi manusia dimuat dalam Pasal 7 sampai dengan 34. Kedua konstitusi yang disebut terakhir dirancang oleh Soepomo yang muatan hak asasinya banyak mencontoh Piagam Hak Asasi yang dihasilkan oleh Perserikatan Bangsa-Bangsa, yaitu The Universal Declaration of human Rights tahun 1948 yang berisikan 30 Pasal. ${ }^{14}$

Dengan Dekrit Presiden RI tanggal 5 juli 1959, maka UUD 1945 dinyatakan berlaku lagi dan UUDS $195^{\circ}$ dinyatakan tidak berlaku. Hal ini berarti ketentuanketentuan yang mengatur hak-hak asasi manusia Indonesia yang berlaku adalah sebagaimana yang tercantum dalam UUD 1945. Pemahaman atas hak-hak asasi manusia antara tahun 1959 hingga tahun 1965 menjadi amat terbatas karena pelaksanaan UUD 1945 dikaitkan dengan paham NASAKOM yang membuang paham yang berbau Barat. Dalam masa Orde Lama ini banyak terjadi penyimpanganpenyimpangan terhadap Pancasila dan UUD 1945 yang suasananya diliputi penuh pertentangan antara golongan politik dan puncaknya terjadi pemberontakan G-30S/PKI tahun 1965. Hal ini mendorong lahirnya Orde Baru tahun 1966 sebagai koreksi terhadap Orde Lama. Dalam awal masa Orde Baru pernah diusahakan untuk menelaah kembali masalah HAM, yang melahirkan sebuah rancangan Ketetapan MPRS, yaitu berupa rancangan Pimpinan MPRS RI No. A3/I/Ad Hoc B/MPRS/1966, yang terdiri dari Mukadimah dan 31 Pasal tentang HAM. Namun rancangan ini tidak berhasil disepakati menjadi suatu ketetapan. ${ }^{15}$

Kemudian di dalam pidato kenegaraan Presiden RI pada pertengahan bulan Agustus 1990, dinyatakan bahwa rujukan Indonesia mengenai HAM adalah sila kedua Pancasila "Kemanusiaan Yang Adil dan Beradab" dalam kesatuan dengan silasila Pancasila lainnya. Secara historis pernyataan Presiden mengenai HAM tersebut amat penting, karena sejak saat itu secara ideologis, politis dan konseptual HAM dipahami sebagai suatu implementasi dari sila-sila Pancasila yang merupakan dasar negara dan pandangan hidup bangsa Indonesia. Meskipun demikian, secara Ideologis, politis dan konseptual, sila kedua tersebut agak diabaikan sebagai sila yang mengatur HAM, karena konsep HAM dianggap berasal dari paham individualisme dan liberalisme yang secara ideologis tidak diterima. ${ }^{26}$

Perkembangan selanjutnya adalah dengan dibentuknya Komisi Nasional Hak Asasi Manusia (KOMNAS HAM) berdasarkan Keputusan Presiden RI No. 50 Tahun 1993 tanggal 7 Juni 1993. Pembentukan KOMNAS HAM tersebut pada saat bangsa Indonesia sedang giat melaksanakan pembangunan, menunjukkan keterkaitan yang erat antara penegakkan HAM di satu pihak dan penegakkan hukum di pihak lainnya. $\mathrm{Hal}$ ini senada dengan deklarasi PBB tahun 1986, yang menyatakan HAM merupakan

${ }^{14}$ Marsudi, Subandi Al., Op. Cit., hlm. 95.

1sIbid., hlm. 96.

${ }^{16}$ Sugondo, Lies., 2001, Perkembangan Pelaksanaan HAM di Indonesia, Kapita Selekta Hak Asasi Manusia, Puslitbang Diklat MARI, hlm. 129.

"Darmodiharjo, Darji., dan Shidarta., 1995, Pokok-Pokok Filsafat Hukum, Jakarta: Gramedia Pustaka Utama, hlm. 164. 
tujuan sekaligus sarana pembangunan. Keikutsertaan rakyat dalam pembangunan bukan sekedar aspirasi, melainkan kunci keseluruhan hak asasi atas pembangunan itu sendiri. Hal tersebut menjadi tugas badan-badan pembangunan internasional dan nasional untuk menempatkan HAM sebagai fokus pembangunan ${ }^{17}$

Guna lebih memantapkan perhatian atas perkembangan HAM di Indonesia, oleh berbagai kalangan masyarakat (organisasi maupun lembaga), telah diusulkan agar dapat diterbitkannya suatu Ketetapan MPR yang memuat piagam hak-hak asasi. Manusia atau Ketetapan MPR tentang GBHN yang di dalamnya memuat operasionalisasi daripada hak-hak dan kewajiban-kewajiban asasi manusia Indonesia yang ada dalam UUD 1945.

Akhirnya ketetapan MPR RI yang diharapkan memuat secara adanya HAM itu dapat diwujudkan dalam masa Orde Reformasi, yaitu selama Sidang Istimewa MPR yang berlangsung dari tanggal 10 sampai dengan 13 November 1988. Dalam rapat paripurna ke-4 tanggal 13 November 1988, telah diputuskan lahirnya Ketetapan MPR RI No. XVII/MPR/1988 tentang Hak Asasi Manusia. Kemudian Ketetapan MPR tersebut menjadi salah satu acuan dasar bagi lahirnya UU No. 39 Tahun 1999 tentang Hak Asasi Manusia yang disahkan pada tanggal 23 september 1999. ${ }^{18}$ Undang-Undang ini kemudian diikuti lahirnya Perpu No. 1 Tahun 1999 yang kemudian disempurnakan dan ditetapkan menjadi UU No. 26 Tahun 2000 tentang Pengadilan Hak Asasi Manusia.

Sebagai bagian dari HAM, sebelumnya telah pula lahir UU No. 9 Tahun 1998 tentang Kemerdekaan Menyampaikan Pendapat Di Muka Umum yang disahkan dan diundangkan di Jakarta pada tanggal 26 oktober 1998, serta dimuat dalam LNRI Tahun 1999 No. 165.
Di samping itu, Indonesia telah meratifikasi pula beberapa konvensi internasional yang mengatur HAM, antara lain:19

a. Deklarasi tentang Perlindungan dan Penyiksaan, melalui UU No. 5 Tahun 1998.

b. Konvensi mengenai Hak Politik Wanita 1979, melalui UU No. 68 Tahun 1958.

c. Konvensi Penghapusan Segala Bentuk Diskriminasi Terhadap wanita, melalui UU No. 7 Tahun 1984.

d. Konvensi Perlindungan Hak-Hak Anak, melalui Keppres No. 36 Tahun 1990.

e. Konvensi tentang Ketenagakerjaan, melalui UU No. 25 Tahun 1997, yang pelaksanaannya ditangguhkan sementara.

f. Konvensi tentang Penghapusan Bentuk Diskriminasi Ras Tahun 1999, melalui UU No. 29 Tahun 1999.

\section{Penegakan HAM di Indonesia}

Tegaknya HAM selalu mempunyai hubungan korelasional positif dengan tegaknya negara hukum. Dengan dibentuknya KOMNAS HAM dan Pengadilan HAM, regulasi hukum HAM dengan ditetapkannya UU No. 39 Tahun 1999 dan UU No. 26 Tahun 2000 serta dipilihnya para hakim ad hoc, akan lebih menyegarkan iklim penegakkan hukum yang sehat. Artinya kebenaran hukum dan keadilan harus dapat dinikmati oleh setiap warganegara secara egaliter. Disadari atau tidak, dengan adanya political will dari pemerintah terhadap penegakkan HAM, hal itu akan berimplikasi terhadap budaya politik yang lebih sehat dan proses demokratisasi yang lebih cerah. Harus disadari pula bahwa kebutuhan terhadap tegaknya HAM dan keadilan itu memang memerlukan proses dan tüntutan

${ }^{18}$ Marsudi, Subandi Al., Op. Cit., hlm. 98.

19 Sugondo, Lies. , Op. Cit., hlm. 146. 
konsistensi politik. Begitu pula keberadaan budaya hukum dari aparat pemerintah dan tokoh masyarakat merupakan faktor penentu (determinant) yang mendukung tegaknya HAM.

Kenyataan menunjukkan bahwa masalah HAM di indonesia selalu menjadi sorotan tajam dan bahan perbincangan terus-menerus, baik karena konsep dasarnya yang bersumber dari UUD 1945 maupun dalam realita praktisnya di lapangan ditengarai penuh dengan pelanggaran-pelanggaran. Sebab-sebab pelanggaran HAM antara lain adanya arogansi kewenangan dan kekuasaan yang dimiliki seorang pejabat yang berkuasa, yang mengakibatkan sulit mengendalikan dirinya sendiri sehingga terjadi pelanggaran terhadap hak-hak orang lain. ${ }^{20}$

Terutama dalam kurun waktu sepuluh tahun terakhir ini, masalah HAM di Indonesia bergerak dengan cepat dan dalam jumlah yang sangat mencolok. Gerak yang cepat tersebut terutama karena memang telah terjadi begitu banyak pelanggaran HAM, mulai dari yang sederhana sampai pada pelanggaran HAM berat (gross $h u-$ man right violation). Di samping itu juga karena gigihnya organisasi-organisasi masyarakat dalam memperjuangkan pemajuan dan perlindungan HAM. ${ }^{21}$

Pelanggaran HAM yang berat menurut Pasal 7 UU No. 26 Tahun 2000 meliputi kejahatan genocide (the crime of genocide) dan kejahatan terhadap kemanusiaan (crime against humanity). Kejahatan genosida adalah setiap perbuatan yang dilakukan dengan maksud untuk menghancurkan atau memusnahkan seluruh atau sebagian kelompok bangsa, ras, kelompok etnis kelompok agama, dengan cara: a. membunuh anggota kelompok; b. mengakibatkan penderitaan fisik atau mental yang berat terhadap anggota-anggota kelompok; c. menciptakan kondisi kehidupan kelompok yang akan mengakibatkan kemusnahan secara fisik baik seluruh atau sebagiannya; d. memaksakan tindakan-tindakan yang bertujuan mencegah kelahiran di dalam kelompok; e. memindahkan secara paksa anak-anak dari kelompok tertentu ke kelompok lain. ${ }^{22}$ Sedangkan kejahatan terhadap kemanusiaan adalah salah satu perbuatan yang dilakukan sebagai bagian dari serangan yang meluas atau sistematik yang diketahuinya bahwa serangan tersebut ditujukan secara langsung terhadap penduduk sipil berupa pembunuhan, pemusnahan, perbudakan, pengusiran, perampasan kemerdekaan, penyiksaan, perkosaan, penganiayaan, penghilangan orang secara paksa dan kejahatan apartheid. ${ }^{23}$

Seperti diketahui, di Indonesia telah terjadi banyak kasus yang diindikasikan sebagai pelanggaran HAM berat, terutama kasus kekerasan struktural yang melibatkan aparat negara (polisi dan militer) dengan akibat jatuhnya korban dari kalangan penduduk sipil. Di antara sederetan kasus yang mendapat sorotan tajam dunia internasional, adalah kasus DOM di Aceh, Tanjung Priuk, Timor-Timur pasca jajak pendapat, tragedi Santa Cruz, Liquisa, Semanggi dan Trisakti. Pelanggaranpelanggaran tersebut dinilai cukup serius dan bukanlah sebagai kejahatan biasa, tetapi merupakan kejahatan terhadap kemanusiaan (crime against humanity). ${ }^{24}$

solbid.

2'Sugianto, Djoko., 2001, Hak Asasi Manusia dan Peradilan HAM, Kapita Selekta Hak Asasi Manusia, Puslitbang Diklat MARI, hlm. 119.

${ }^{22}$ Pasal 8 UU No. 26 Tahun 2000.

${ }^{23}$ Pasal 9 UU No. 26 Thun 2000.

${ }^{24}$ Suryokusumo, Sumaryo., 2001, Prosedur Penyelesaian Konflik dalam Kerangka Pelanggaran Hak Asasi Manusia, Kapita Selekta Hak Asasi Manusia, Puslitbang Diklat MARI, hlm. 303. 
Munculnya berbagai kasus pelanggaran HAM berat telah melahirkan kesadaran kolektif tentang perlunya perlindungan HAM melalui instrumen hukum dan kinerja institusi penegak hukumnya. Banyak kasuskasus pelanggaran HAM berat atau yang mengandung unsur adanya pelanggaran HAM yang selama ini tidak tersentuh oleh hukum, sebagai akibat dari bergulirnya reformasi secara perlahan tapi pasti mulai diajukan ke lembaga peradilan. Lembaga peradilan, dalam hal ini Pengadilan HAM, merupakan forum paling tepat untuk membuktikan kebenaran tuduhan-tuduhan adanya pelanggaran HAM di Indonesia. Pasal 104 ayat (1) UU No. 39 Tahun 1999 secara tegas menyatakan bahwa untuk mengadili pelanggaran HAM yang berat dibentuk Pengadilan HAM di lingkungan Peradilan Umum. Hukum acara yang berlaku atas perkara pelanggaran HAM yang berat menurut Pasal 10 UU No. 26 Tahun 2000, dilakukan berdasarkan ketentuan hukum acara pidana, kecuali ditentukan lain dalam Undang-Undang ini.

Dibentuknya Pengadilan HAM di Indonesia patut disambut gembira, karena diharapkan dapat meningkatkan citra baik Indonesia di mata internasional, bahwa Indonesia mempunyai komitmen dan political will untuk menyelesaikan berbagai kasus pelanggaran HAM berat. Seiring dengan itu upaya penegakkan HAM di Indonesia diharapkan mengalami peningkatan yang cukup signifikan.

\section{Kesimpulan}

HAM adalah persoalan yang bersifat universal, tetapi sekaligus juga kontekstual. Setiap negara mempunyai sejarah perjuangan dan perkembangan HAM yang berbeda, oleh karena itu konsepsi dan implementasi HAM dari suatu negara tidak dapat disamaratakan. Adanya HAM menimbulkan konsekwensi - adanya kewajiban asasi, keduanya berjalan secara paralel dan merupakan satu kesatuan yang tak dapat dipisahkan. Pengabaian salah satunya akan menimbulkan pelanggaran HAM, dan Islam telah memberikan pedoman yang sangat jelas mengenai masalah ini.

Perkembangan dan perjuangan dalam mewujudkan tegaknya HAM di Indonesia terutama terjadi setelah adanya perlawanan terhadap penjajahan bangsa asing, sehingga tidak bisa dilihat sebagai pertentangan yang hanya mewakili kepentingan suatu golongan tertentu saja, melainkan menyangkut kepentingan bangsa Indonesia secara utuh.

Dewasa ini, meskipun ditengarai banyak kasus pelanggaran HAM berat di Indonesia, tetapi secara umum Implementasi HAM di Indonesia, baik menyangkut perkembangan dan penegakkannya mulai menampakkan tanda-tanda kemajuan. Hal ini terlihat dengan adanya regulasi hukum HAM melalui peraturan perundangundangan. Di samping itu telah dibentuknya Pengadilan HAM dalam upaya menyelesaikan berbagai kasus pelanggaran HAM berat yang terjadi.

\section{Daftar Pustaka}

Alkostar, Artidjo., 1994, “Hak Asasi Manusia dalam Perspektif Penegakkan Hukum Dewasa Ini", Makalah dalam rangka Dies Natalis UII ke 51, Yogyakarta.

Ahadian, Ridwan Indra ., 1991, Hak Asasi Manusia dalam UUD 1945, Jakarta: CV. Haji Masagung.

Darmodiharjo, Darji., dan Shidarta., 1995, Pokok-Pokok Filsafat Hukum, Jakarta: Gramedia Pustaka Utama.

Mahfud, Moh., 1999, Hukum dan Pilarpilar Demokrasi, Yogyakarta: Gama Media, Yogyakarta.

Marsudi, Subandi Al ., 2001, Pancasila dan UUD' 45 dalam Paradigma Reformasi, Jakarta: PT RajaGrafindo Persada.

Natsir, Moh., 1953, Dapatkah Dipisahkan Politik dan Agama?, Jakarta: Mutiara. 
Konsepsi Hak Asasi Manusia dan Implementasinya di Indonesia

Luthan, Salman, "Proyeksi Harmonisasi Konvensi Menentang Penyiksaan Dengan Hukum Pidana Nasional", makalah seminar nasional kerjasama Departemen Hukum Internasional FH UII dengan ELSAM, Yogyakarta, 1995. Sugianto, Djoko., 2001, Hak Asasi Manusia dan Peradilan HAM, Kapita Selekta Hak Asasi Manusia, Puslitbang Diklat MARI.

Sugondo, Lies., 2001, Perkembangan Pelaksanaan HAM di Indonesia, Kapita Selekta Hak Asasi Manusia, Puslitbang Diklat MARI.
Suryokusumo, Sumaryo., 2001, Prosedur Penyelesaian Konflik dalam Kerangka Pelanggaran Hak Asasi Manusia, Kapita Selekta Hak Asasi Manusia, Puslitbang Diklat MARI.

Tap MPR RI No. XVII/MPR/1998 tentang Hak Asasi Manusia.

UU No. 39 Tahun 1999 tentang Hak Asasi Manusia.

UU No. 26 tahun 2000 tentang Pengadilan HAM. 